
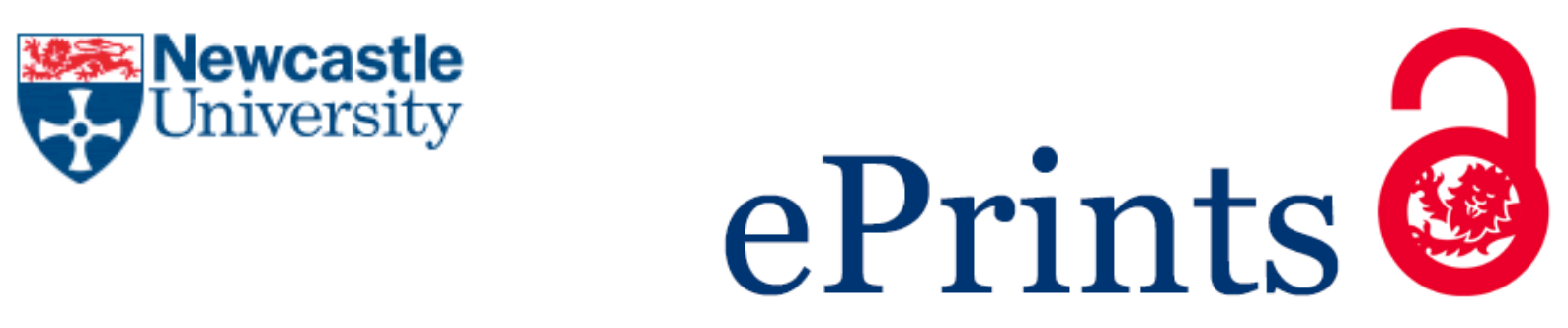

Whittle A, Mueller F. Strategy, enrolment and accounting: The politics of strategic ideas. Accounting, Auditing and Accountability Journal 2010, 23(5), 626-646.

\title{
Copyright:
}

This article is (c) Emerald Group Publishing and permission has been granted for this version to appear here http://eprint.ncl.ac.uk/pub details2.aspx?pub id=189789. Emerald does not grant permission for this article to be further copied/distributed or hosted elsewhere without the express permission from Emerald Group Publishing Limited.

The definitive version of this article, published by Emerald Group Publishing, 2010, is available at http://dx.doi.org/10.1108/09513571011054918

Always use the definitive version when citing

Further information on publisher website: www.emeraldinsight.com

Date deposited:

$11 / 05 / 2015$ 
This is the author(s) personal version of the manuscript, as accepted after the review process but prior to final layout and copyediting by the publisher. The final version is published as:

Whittle, A. \& Mueller, F. (2010) Strategy, Enrolment and Accounting: The Politics of Strategic Ideas. Accounting, Auditing \& Accountability Journal 23(5): 626-646.

Formatted: Font: $10 \mathrm{pt}$

Formatted: Indent: First line: $0 \mathrm{~cm}$

Readers are kindly asked to use the official publication in references.

\section{Strategy, Enrolment and Accounting: The Politics of Strategic Ideas}

Paper submitted to Accounting, Auditing \& Accountability Journal Special Issue on 'Accounting for Politics: Power/Strategy/Accountability'

[Words: 10,378 incl references, abstract and title page.] 


\section{A}

Purpose - The purpose of this paper is to use Actor Network Theory to explore the role of management accounting systems (MAS) in the construction of business strategy.

Design/methodology/approach - The paper draws on findings from an ethnographic study of a UK-based firm. Theoretical concepts from Actor-Network Theory are used to illuminate the findings of the study.

Findings - The study found that MAS acted as an obligatory point of passage into the strategic agenda of the firm. However, our findings also reveal the political tactics used by employees in order to work within, against and around the MAS.

Originality/value - The paper shows that MAS are a key player in the political contests that occur during the process of strategy formulation, as opposed to offering a neutral tool for measuring the strategic value of innovative ideas.

Keywords - Accounting, Politics, Power, Strategy.

Paper type - Research paper 


\section{Introduction}

Why do some ideas turn into 'strategies' when others do not? If strategy is influenced by social, political and institutional forces as opposed to being based on a rational assessment of core competencies or market opportunities, we cannot assume that certain ideas offer inherently greater added value than others. Instead, the question becomes: why do some ideas become regarded as strategic while others do not? In this paper, we draw upon the findings of an ethnographic study of a UK firm to examine the role of management accounting systems (MAS) in the construction and legitimation of strategic ideas. Drawing inspiration from Actor Network Theory (ANT), we show how MAS acted as obligatory points of passage in the construction of organizational strategy. However, our findings also reveal spaces for resistance, deviance and voice within an existing MAS. We argue that accounting regimes play a key role in defining the 'added value' of ideas, with implications for how business strategies are formulated.

\section{Accounting and the Making of Strategy}

The growing field of 'strategy as practice' (SAP) has been valuable in de-mystifying the concept of 'strategy' and revealing the practices that underlie how strategies are made and implemented. This field mirrors the so-called 'turn to practice' within accounting research (Ahrens \& Chapman, 2007a). The SAP field has shifted the terms of the debate away from what strategy an organization should have towards viewing strategy as something people do (Whittington, 1996, 2003, 2004; Johnson, Melin \& Whittington 2003). However, current work has yet to interrogate how certain ideas become transformed into 'strategies' while others do not. If we accept that ideas must be made into 'strategic' ideas, as opposed to having a 'strategic' essence to them, we need to study how ideas become strategic.

\section{The Politics of Strategy}

Current thinking within SAP has recently been criticised for its lack of attention to issues of power and politics (Carter, Clegg \& Kornberger, 2008a, 2008b). Given that power is central to organizational life (Clegg, Courpasson \& Phillips, 2006), this omission leaves the SAP field with a tendency to view strategy as a neutral process of deciding on the direction of a business (Carter, Clegg \& Kornberger, 2008a: 87). Yet, according to Clegg, Carter and Kornberger (2004: 25), “[u]nderstanding of strategy 
necessitates an engagement with power and politics." What counts as a 'strategic' idea or function is thus an outcome of power struggles between organizational groups vying to control the agenda.

Carter and Mueller's (2002) study of a UK utility company reveals the power and politics underlying strategic change. The authors found a tension between the 'professional archetype' favoured by the professional engineers and the 'managerialist archetype' favoured by the incumbent managers. Both groups sought to undermine the position of the other through reference to the strategic objectives of the firm, in order to defend and/or extend their power, status and resources. Similar power battles and political contests have been observed in studies of strategic change in other professional groups, such as Mueller, Harvey and Howorth's (2003) study of how doctors used certain discursive strategies in order to defend their point of view. What counts as 'strategic' is therefore an outcome of power struggles and political battles, not a neutral outcome of rational thought about core competencies, markets and environments (Carter \& Mueller, 2006). In fact, what 'being strategic' or 'doing strategy' involves has shifted considerably according to the changing fads and fashions in strategic thought, from the emphasis on strategic planning in the 1950s and 1960s, to the focus on environmental forces following the work of Michael Porter in the 1980s, to the more recent emphasis on core competencies and emergent strategy (Mintzberg, 1994).

The debate about what counts as 'strategy' can also be linked to broader shifts in discourse about corporate strategy that act to reproduce inequality, power and privilege across society (Knights \& Morgan, 1991: 251). For example, managers may account for their work in terms of the discourse of 'strategy' (rather than, say 'management') in order to provide them rationalisations for their actions that enhances and sustains the exercise of managerial power (Knights \& Morgan, 1991). Strategy is also the result of (a certain constellation of) power. For example, a power struggle may leave certain functions such as finance and marketing being regarded as 'strategic', while other groups such as HR and IT are regarded as merely 'operational'. In turn, strategy will give rise to (unequal distribution of) power: a strategy of globalisation, for example, will reduce the power of 'national barons'. Accounting can play a key role in these power battles. For example, Dent (1991) shows how an MAS was used to transform the engineering culture of nationalised railway organization towards a more commercially oriented culture, resulting in shifts 
in power centres within the organization away from engineers towards the new 'Business Managers'.

The emergence of certain 'discursive fields' allows certain ways of speaking and calculating. For example, when the State emerges as a 'linguistic device' then new ways of articulating and conceptualising the ruling of a population become feasible (Miller \& Rose, 2008: 57). Equally, strategy discourse also has self-disciplining power effects upon subjects (Rose, 1999), designed to transform employees into more manageable and efficient entities (Miller \& O’Leary, 1987). Alvesson \& Willmott (1996: 134) argue that "the adoption of strategy-talk has self-disciplining effects as employees contrive to gain credibility and influence by demonstrating and promoting the relevance of their work for attaining objectives that are deemed to be 'strategic'”. Technologies of managing such as accounting are "sedimented with asymmetrical power relations and reproduce structures of differential access to material and symbolic goods” (Alvesson \& Willmott, 1992: 12). Therefore, it is to the accounting literature that we now turn.

\section{How Accounting (Devices) Create(s) Reality}

The discipline and practice of accounting plays a central role in the governance of contemporary organizations. In fact, accounting seems to enjoy an almost hegemonic status in Western firms (Ezzamel, Lilley and Willmott, 1997). Accounting, it seems, has asserted itself as the dominant discourse within the firm. Critical scholarship, however, has sparked intense debate about the ethics and efficacy of accounting techniques and the political implications of such dominance. The field of critical accounting has been valuable in questioning the idea that accounting systems are neutral "tools for measuring and allocating economic resources" (Quattrone, 2004: 647). For example, critical research has moved beyond the idea that management accounting systems (MAS) help organizations to make "sensible, considered, and goal-directed decisions about the best use of organizational resources” (Baxter \& Chua, 2006: 43) towards understanding how accounting systems are connected to "the local goals of various political coalitions within organizations” (ibid, p. 45). This critical research agenda has enabled us to understand the role of accounting in the creation of new forms of self-disciplining subjects (Miller \& Rose, 1990; Roberts, 1991: 358-360), where subjects are led to question the added value they bring to the firm and see their actions in terms of the performance measurement systems they 
work within (Ahrens and Chapman, 2007a). In addition, critical research has brought attention to the role of accounting within the development of 'new managerialism' (Hoskin \& Macve, 1988), the extension of control over the workforce (Ezzamel, Willmott \& Worthington, 2004), and even "darker" issues of ethics and exploitation following corporate scandals such as Enron (eg. Owen, 2005).

Our study is located in the more general school of thought that views accounting as a social, political and institutional practice (Hopwood \& Miller, 1994). Following this approach means that we must first try to understand the social and political processes through which particular norms (such as standard costing) come about. What is accepted as standard practice today, was once not accepted or was outsider knowledge. Miller (1998, p.175) shows that “(d)evices that had apparently served firms successfully for many years are now seen to be inherently flawed. The boundaries of accounting are being redrawn ...”. Such redrawings are the result of contestations between different discourses or interests. In this way, accounting can contribute to "a more general project of socio-political management" (Miller \& O’Leary, 1987: 262).

Second, we must understand the "historical contingency of contemporary practices ... We need to think in terms of multiple and dispersed surfaces of emergence of disparate and often humble practices ...” (Miller \& Napier, 1993: 633). By implication, any company's accounting regime at a particular time is ultimately contingent and this means that something else is always possible. The emergence of one regime, rather than another, links to the outcomes of power struggles within the firm and its institutional context. Third, we should not only focus on economics/accounting as a form of representing reality but, simultaneously, as a way of making reality: both economics and accounting perform, shape and format the economy rather than only observing it (Callon, 1998a: 2). The introduction of devices such as profit centres, investment centres, cost centres, is "to change lines of responsibility and the possibilities of action by a change in the form of visibility" (Miller, 1994: 2). We must recognise therefore that market regimes or accounting regimes are not naturally given, but are made by us. In some cases they are interlinked: for example, new calculative instruments linking clinical and financial categories helped to create new markets in the field of health care (Miller \& O’Leary, 2007: 731). 


\section{Actor Network Theory}

ANT, or the 'sociology of translation' as it is also known, was first developed in the sociology of science as a methodology for understanding how actors (whether human or non-human) are enrolled into a network around an idea. ANT looks at how robust networks are built through a process of heterogeneous engineering (Law, 1986) that make certain ideas - such as scientific theories - become regarded as 'truth'. A heterogeneous engineer in a science laboratory, for example, brings together a complex of funding, research articles, scientific equipment, tables, diagrams, charts, research assistants and scientific allies to form a successful research programme (Latour, 1987). What counts as 'scientific truth', then, is based on who is able to assemble the most robust network around a particular idea.

Callon's (1986) seminal study of scallop fishing showed how a group of scientists attempted to become obligatory points of passage - the only path through which the actors can further their interests, in this case the successful fishing of deepsea scallops. Callon sets out a four stage process through which new social relationships were constructed between scientists, fishermen and scallops in St. Brieuc Bay, France. The first stage Callon defines as problematization, where networkbuilders, in this case the scientists, render themselves indispensable. The research report created by the scientists, for instance, sought to become an obligatory point of passage by convincing the scallops, their scientific colleagues and the fishermen that the proposed research program was the only way to pursue their interests. In the second stage, interessment, tactics are used to bring the allies together, to overcome resistance and competing problematizations and solidify the network. A range of strategies and mechanisms are used, including non-human elements, such as the towlines and collectors used to propagate the scallops and protect them from predators. Interessment, if successful, then validates the original problematization and the allegiances it involves. The third stage, enrolment, is achieved only when interessment has been successfully accomplished. Their fellow scientists must be convinced by the experiment, the fishermen must accept and implement the conclusions they draw and the scallops must be willing to anchor themselves to the collectors. The fourth and final stage described by Callon is one of mobilization. In this stage, the durability of the network is only established when the representatives or spokespersons are able to mobilize others as allies in the network. Scientific tallies, tables, graphs and ballot methods are all involved here. In a successful mobilization 
actors are displaced and then reassembled in a different time and place, in this case into the form of tables and diagrams in a conference room. The actor-network, then, is the result of a negotiation regarding the representativeness of the spokesmen, in this case the scientific researchers.

ANT has been described as one of the key approaches in accounting research (Lounsbury, 2008: 356; Ahrens and Chapman, 2007a). For example, with reference to the strawberry market in the Sologne region of France, Callon (1998a: 20) outlines that material investments were needed (purpose-built warehouses) and a 'space of calculability' was created including the technique of degressive bidding, electronic display of transactions, use of data slips and knowledge of the national market. To date, ANT has been applied within accounting research to the understanding of how accounting systems enable "government at a distance" (Miller \& Rose, 1990; Miller \& Rose, 2008) and "action at a distance” (Robson, 1992; Preston, 2006), the adoption (or otherwise) of a new accounting system in Australian hospitals (Chua, 1995), the implementation of open book accounting and target cost management in two Danish firms (Mouritsen, Hansen \& Hansen, 2001), the introduction of activity-based costing in a large Australian aluminium manufacturer (Briers \& Chua, 2001), attempts to introduce standard costing systems in a Malaysian manufacturing firm (Lowe \& Koh, 2007) and the process through which government auditors in Canada construct their expertise (Gendron, Cooper \& Townley, 2007).

We follow ANT's approach to understanding how 'scientific truth' depends on the construction of a robust network around a scientific theory by exploring how what counts as a 'strategic' idea depends on the representations of 'value' in management accounting systems. The power of networks depends on the action of intermediaries, or "mediating instruments", such as "written documents, technical artefacts, human beings, or money” (Miller \& O’Leary, 2007: 710). The “calculating tools” (ibid) of accounting are one such mediating instrument through which markets are created, such as the 'quasi-markets' within the firm that are simulated by management accounting systems, as we examine in this study. However, Ahrens and Chapman (2007b: 104) argue that the contribution of ANT is best realised by "studies inspired by ANT rather than straightforward applications of it”. Hence we seek to draw on some key concepts from ANT, such as the concepts of heterogeneous engineering and obligatory points of passage, rather than seek to replicate Callon's (1986) four stages of translation described above. 
Skærbæk \& Tryggestad's (2009) study of 'Scandlines', the ferry division of the Danish, government-owned railway company DSB, explores "the role that accounting devices can play as people become skilled strategists” (p.1). A stream of accounting devices established a boundary (frame), within which certain devices operate in specific ways (p.3). Examples of accounting devices include laboratory simulations, cash flow scenarios, the IPO, the corporate balance sheet, the government budget (p.6). For example, the payback device took certain strategic options off the agenda, for instance by preventing investment in ferry operations. Accounting, then, is not simply a mechanism for implementing and monitoring strategy: it also actively shapes how strategic matters are formulated and decided. As Skærbæk and Tryggestad (2009) argue, "accounting devices become strategic in a role of (re)formulating strategic ends and rationales, rather than being limited to implementation” (p.14).

The notion of 'overflowing' (Callon, 1998b: 254-5) refers to the impossibility of totally internalizing externalities: for example, the implicit parts of the contract or the unintended consequences of a strategic plan. Attempts to account for all elements in a calculation will bring about 'overflow' and new externalities and eventualities. Strategy produces overflows in terms of emerging concerns and resistances (Skærbæk \& Tryggestad, 2009: 8). "Accounting is an integral part of framing strategy, that is to say the accounting devices become strategic in a role of (re)formulating strategic ends and rationales, rather than being limited to implementation.” (ibid, p.14) This also means that the notion of a strategic centre needs to be problematized: the strategic actor's identity, for example top management's, went from 'company developer' to ‘company butcher' (p.15).

According to Dent (1990: 21), "[r]esearch at the interface between accounting and strategy is, as yet, underdeveloped”. Naranjo-Gil and Hartmann's (2007) survey study found that management accounting systems are closely correlated with the strategic decisions made by senior management. However, this statistical data gives us little understanding about how accounting is actually implicated in the making of strategic ideas. Drawing on concepts from Actor Network Theory, we will show how management accounting systems act as an 'obligatory point of passage' in deciding which ideas succeed (and which fail) in becoming regarded as "strategic". In so doing, we address Dent's (1990: 21) call for research into the relationship between 
accounting systems, organizational control and the process of strategic decisionmaking.

\section{Methodology}

Case Study. FlexiTeam were a group of ten 'flexible working' consultants employed by UK telecommunications firm TeleCo. The consultants used the term 'flexible working' broadly to refer to the use of technology to work flexibly in time and/or space. FlexiTeam advised external clients on how to implement home-working, hotdesking, mobile working, virtual teams and related facilities management, human resource management and real estate issues. Their consultancy methodology included questionnaires, interviews, focus groups, workshops, geographical mapping technology and space utilisation surveys.

Research design. The study was designed following the so-called 'naturalistic' tradition in accounting research (Baxter \& Chua, 2006). Naturalistic researchers are “united in their concern for studying management accounting in its 'everyday' or ordinary context" (ibid: 46). The study took an ethnographic approach and sought to gain an in-depth understanding of the working lives of the consultants through nonparticipant observation and semi-structured interviewing. Ethnographic research has the advantage of enabling the researcher to observe how organizational processes emerge over time, and how people make sense of the accounting systems they work within (Mouritsen, 1999). Our aim was to try to understand the meanings that were constructed in and around the accounting systems, as opposed to researching the accuracy or efficacy of the accounting systems themselves. Following ANT's principle of relativism, we remain deliberately sceptical about the truth claims made by the participants: for instance, with regard to questions around whether the accounting calculations were "right" or "wrong”. Rather, following ANT, our interest was in how claims to truth are constructed.

Data collection. The fieldwork was conducted between 1999 and 2003 and involved non-participant observation of team meetings, one-to-one performance reviews, exhibition and presentation activities, client workshops, sales events, home visits and social activities, in addition to gathering documentation and studying audioconferences and email exchanges within FlexiTeam (see table in Appendix for full 
details). The observational data was particularly important in this study because it enabled us to examine "the actual calculative practices of actors at work" (Miller \& O’Leary, 2007: 711). As Ahrens and Mollona (2007: 307) argue, “ethnography ... can be very useful for producing longitudinal observations of organisational everyday life through which the functioning of accounting and control can be most fully appreciated”. The semi-structured interviews were also adapted to include questions based on the ongoing insight derived from the fieldwork observations. In total, the study generated four notebooks of field-notes, over a hundred email exchanges, over sixty hours of tape-recorded interviews and audio-conference recordings and numerous paper and electronic documents, leaflets, brochures and files.

Data analysis. As an inductive and exploratory study, the aim of data analysis was not to compare our findings with pre-defined hypotheses. Nor was our aim to simply represent "what happened" in the field. Instead of simply reproducing the interpretations that were prevalent in the field, our approach was to work at the boundary between the emic (the meaning-systems used by those in the field) and etic (the meanings used by the researcher to interpret observations), in order to produce a new interpretation of 'what is going on here' (Barley \& Kunda, 2001). Merely repeating the stories told by the respondents would be unlikely to add much to theory development. The themes and sub-titles used in this article were therefore constructed through an iterative movement between the data and our reading of the literature, in particular with inspiration from ANT.

\section{Accounting, Politics and the Battle of Ideas}

The consultancy team at the centre of this study were employed by a large UK-based telecommunications company called 'TeleCo' (all names are pseudonyms). Since TeleCo was privatised in the mid-1980s, the company undertook a series of changes to modernise its operations. As part of this modernisation programme, internal departments were re-structured into quasi-autonomous 'business units', treated as distinct 'cost centres'. Business units were held individually accountable for revenue and costs, in an attempt to use MAS to simulate market conditions within the firm. These changes are typical of the simulated 'quasi-markets' associated with postbureaucratic transformations (Ahrens \& Chapman, 2006). A recent example is the 
creation of pseudo-markets for greenhouse gas emissions to be traded (Malone, 2004; MacKenzie, 2007).

The team of management consultants at the centre of this paper was founded by TeleCo employee Eric. Eric was a 'born and bred' Londoner with a background in corporate property management. His first job in TeleCo was in the Property Division, but he had aspirations beyond this role. He saw himself as a visionary thinker that would single-handedly try to transform the way TeleCo did business by getting TeleCo into the business of "selling solutions" rather than "selling products". In the late 1980s, Eric developed a "big idea" during his MBA dissertation about how to use technology to enable employees to work flexibly in time and space. Examples include home-working, working "on the road”, hot-desking and virtual teamwork. When he then "sold" this idea to the board of directors of TeleCo, it resulted in the largest corporate flexible working programme in the UK, at the same time as making huge savings for TeleCo from selling off prime-location office buildings. However, the focus of this paper is on Eric's next "big idea", started in the mid-1990s, to set up a management consulting group to sell their "expertise" on how to implement flexible working to external clients. The "big idea" here was to find a radically new way to sell TeleCo's telecommunications products. Instead of selling their products on the basis of their features (eg. a fast broadband internet connection speed), Eric and his consultants would "help" clients to "improve" their business - by implementing working from home for example - in order to "create" new customer "needs" for TeleCo's products.

For TeleCo, Eric's idea was a radical shift away from their current marketing strategy. TeleCo had traditionally followed a strategy of expansion into new telecommunications product and service markets, including the newly emerging market for internet and mobile telephony, coupled with consolidation of their position in existing markets such as domestic telephone lines. The consultants called this "consulting-led selling”, in contrast with the current "direct selling approach" where sales representatives try to show how their products help to meet their customers' preexisting "needs". The consultants presented the contrast between the two strategic options in a table that was circulated on the group email distribution list (which included the researcher): 


\begin{tabular}{|l|l|}
\hline \multicolumn{1}{|c|}{ Traditional Selling } & \multicolumn{1}{c|}{ Consulting-led Selling } \\
\hline Seller provides product & Seller provides profit as the product \\
\hline $\begin{array}{l}\text { Seller attempts to justify the cost of } \\
\text { product }\end{array}$ & $\begin{array}{l}\text { Seller offers a return on the } \\
\text { customer's investment }\end{array}$ \\
\hline Seller emphasises product features & Seller helps the customer \\
\hline
\end{tabular}

(based on information circulated by email)

In short, rather than market products on the basis of features (technology-push), the consulting-led selling approach would instead attempt to understand the customer's business in order to recommend technology that adds value to the business (businessdriver pull). In this paper, we analyse how FlexiTeam negotiated the 'added value' of this 'consulting-led selling' model, paying particular attention to the role of accounting techniques in this process.

\section{Setting the Scene: The Crisis}

At the time of the study, TeleCo were in the middle of a financial crisis. The company had just reported a record level of corporate debt, leading the share price to plummet. Team leader Eric broke the news to his team during an audio-conference. All business units had been told they had to generate "profit” or risk being disbanded or closed down and redeployed to other "profitable" units. Accounting, then, just like economics, does not simply observe the 'outside', but shapes it (Callon, 1998a). The consultants knew exactly what this meant. They monitored their 'balance sheet' very closely every month because their group bonus depended on hitting targets of client income. The problem was that their current performance, according to the MAS, did not look good. They were measured on the basis of consulting income against costs, as opposed to the sale of TeleCo products or services generated by their consulting activities. This meant they were currently regarded as a 'cost covering' rather than 'profit generating' unit: these can be seen as different 'calculative devices' (Callon, 1998a). The 'translations' offered by the MAS can be depicted as follows: 


\begin{tabular}{|l|l|}
\hline Translation 1 & $\begin{array}{l}\text { Strategy is about deciding what business the } \\
\text { organization should be in. }\end{array}$ \\
\hline Translation 2 & $\begin{array}{l}\text { This relies upon knowing the added value of different } \\
\text { organizational activities in different markets. }\end{array}$ \\
\hline Translation 3 & $\begin{array}{l}\text { Management accounting techniques can objectively } \\
\text { measure the value of different business units. }\end{array}$ \\
\hline Translation 4 & $\begin{array}{l}\text { Accounting is a faithful ally and obligatory point of } \\
\text { passage in strategic decision-making. }\end{array}$ \\
\hline
\end{tabular}

Being classified as 'unprofitable' (according to the MAS translation) shaped the expectations, goals and, thus, actions of the consultants. Business development manager Nigel explained in our interview:

"We are an expensive luxury. If we worked for any other corporate, we wouldn't be there. Being consultants you are natural fee earners, and we aren’t at the moment covering our costs. ... Our salaries as a team come to £x, including cars and technology. This year we're going to recover that $£ x$, so we're a cost recovery unit. ... In real terms, sales managers have 10 people doing $\mathrm{Ex}$ million each ... We're 10 people covering our costs. I'm sure someone somewhere would rather have 10 people bringing in Ex million, rather than this intangible thing, which may or may not be adding value.”

(Consultant Kevin, interview)

As it is clear from this interview, the current MAS made the consultants very anxious.

They were aware of just how precarious and marginal their position was. The consultants worried that their team might be disbanded, downgraded or merged with another team. None of these options were attractive to a team that cherished their jobs, their status, their reputation and their 'intellectual property'. Duncan explained in our interview how anxious this made him feel:

"The survival of the team, is based on selling consultancy services. ... So that we have survival, survival in the organization, we're constantly trying to get new clients in. With the turmoil you've always got to think about the future. Sad to say, but how are you going to last for 2 years? ... How are we going to survive? ... [It] makes me a little bit nervous. I see [other department] dissolving and there could be job losses. ... [if you] talk to people in other parts of the business, like sales, and they say ... our target is to get the amount of business that is their T\&S [travel and subsistence budget] for the year. So it's really small. We're small in terms of volume, but that's what we're trying 
to change, and I think we're succeeding. Our volume is going up - we're selling more consultancy services.”

(Consultant Duncan, interview)

From what Duncan said in his interview, it is clear that the consultants seemed to internalize the anxiety generated by the accounting regime. Similar to the study by Deetz (1998), the creation of an "internal market” (Ahrens \& Chapman, 2006: 6) led the consultants to see themselves as "in business for themselves" and responsible for the creation of profit. However, it also had implications for the legitimacy of the "big idea” they were championing - the idea of consulting-led selling. Here we focus on the implications of the MAS for the construction of organizational strategy. Nigel explained how the accounting regime affected their "appearance" of creating "added value” for the company in our interview:

"In terms of ratios we're covering our overheads, but we're not generating profit. Or the profits and revenues that we generate are identified somewhere else it would never be correlated back to us."

(Consultant Kevin, interview)

The consultants believed that their consulting activities led to new demands for TeleCo's products (such as broadband connections for home-based workers, for instance), but the accounting system did not correlate that revenue back to their activities. Their own business unit was only credited with the direct revenue from consulting fees charged to clients, not the product sales that they "created" as a result of their client work. It is thus the accounting system that 'creates' the sale but also creates dissatisfaction or resistances as unplanned externalities, or in Callon's (1998b) words, 'overflowing'.

While the consultants saw themselves as champions of an innovative new marketing strategy they called "consulting-led selling", the MAS meant their idea failed to be seen as a "value-adding activity" because their work was deemed as "unprofitable”. Thus, success/failure is not an unmediated outcome of the market but a mediated outcome of certain accounting devices. The MAS acted as an obligatory point of passage for the consultants to have their idea recognised as a "strategic competitive advantage". The MAS meant the consultants were under threat of seeing their idea abandoned, rather than shaping the strategic agenda. However, the 
consultants also employed a range of political tactics to work with, against and around the accounting network, to which we will now turn.

\section{The Word Game}

The first tactic involved playing a game of rhetoric and persuasion. The researcher observed the "sales pitch" used to persuade senior management of the value of their innovative marketing strategy at numerous occasions. They 'talked up' the value of consulting-led selling and 'talked down' the value of direct selling. In their research, Sillince \& Mueller (2007) found that talking up and talking down can exist contemporaneously: one is used in order to manage getting more resources; the other one is used in order to manage accountability and being held responsible.

When senior management were not present, they performed sarcastic impressions of the dominant 'direct selling' approach, opening their suit jackets and putting on a 'cockney' accent to say "wanna buy some kit", like a street trader trying to 'flog' stolen watches from inside their jackets. This ritualistic symbolic performance brought about powerful imagery of what was, in their view, the crude and unsophisticated marketing strategy of the firm, to be contrasted with the superiority and sophistication of their 'consulting-led selling' approach. Of course, this cockney impression was not repeated to senior managers: a more subtle approach would be required here. TeleCo were constantly re-structuring their business in attempts to modernise and streamline their operations. After one such re-organization, the consultants found themselves in a different business section with a new manager called Steve. Each re-structuring left the consultants worried about how long they might 'last'. Given their status as an 'unprofitable' unit according to the MAS, they were acutely aware of how important it was to justify their existence and emphasise the value they add to the business: a case of "sink or swim" in their words. During the meeting with Steve, the researcher observed an elaborate and impressive performance. The consultants told Steve about their "strategic value" and 'slipped in' to the conversation details of large contracts they had recently secured. The consultants spent much of their time emphasising their "wider value" to the business and explaining that the way they are measured does not measure them properly. Barry explained: 
“We don't wanna be selling boxes and wires 'cause then the relationship [with the client] is not there - we would just be a wholesale supplier. Like with [Client A], ... they only decided to buy the kit after I'd done a vision workshop with them. But how do you put that down tangibly that they only bought it 'cause we gave them the vision? How do you measure that? That's the problem, we are not credited for all the work we do to make things happen.”

(Consultant Barry, fieldnotes)

Steve nodded and appeared to agree and empathise. However, the consultants were not convinced they had done a good job of persuading their boss that the accounting system was an "unfaithful" ally that failed to measure the "true value" of their innovative consulting-led selling approach. Steve informed them of a new more ambitious target for consulting revenue, passed down from his boss at the last senior management meeting. After Steve had left the room, consultants Darren, Georgina and Barry voiced their concern about their new boss:

Darren: “He didn't seem to have a clue about what we actually do. He didn't seem to understand what consultancy is all about, it's not just about the fees it's about the kit that wouldn't get sold if it wasn't for us."

Georgina: "Yeah, I was a bit worried, all he seemed to care about was the fees."

Barry: "If he can't see past selling boxes and wires then we are all screwed!”

Kevin then joked that he should "cut his wrists now", signalling his pessimism about their future in the company - and by definition the future of their consulting-led selling idea. Although the consultants were convinced of the strategic value of their idea, the MAS seemed to be the only point of passage into the strategic agenda decided by senior management. As long as senior management saw their unit as "unprofitable”, consulting-led selling was unlikely to get onto the strategic agenda of the company. As an obligatory point of passage into what counted as "strategic", numbers seemed to speak louder than words. The consultants attempted to "open the black box" of the accounting system by using persuasion, but ultimately failed to problematize the translation of their "strategic value" into accounting numbers. Put simply, without the right 'numbers' it is unlikely that an idea will turn into a strategy.

\section{The Numbers Game}


Given the power of numbers, FlexiTeam found many, some quite creative, methods to improve their 'balance sheet' or demonstrate their 'value'. One example was the tactic they used to increase their consulting income by increasing the referrals they got from account managers. Many potential clients - and therefore potential fees that would improve their 'balance sheet' - were being missed because account managers did not pass on hints and tips to the consultants. FlexiTeam's creative solution involved a non-human actor, the database used by account managers. The researcher observed a lengthy political battle to get "flexible working" added to the database so that account managers would receive commission on any consulting work that resulted from their referral. This tactic neatly demonstrates two key concepts from ANT: first, heterogeneous engineering (enrolling human and material actors into a network) (Law, 1986) and second, the alignment of interests (convincing actors it is in their interests, "I want what you want”) (Preston, 2006: 562). By bringing the database into their network and offering incentives to account managers, the consultants were able to improve the appearance of their "strategic value".

The consultants knew that corporate conferences and exhibitions were a key source of new client business, but these events were not 'billable' to any particular client and did not improve their income/cost ratio. As a result, team leader Eric decided to change his approach to sending his consultants to events organized by other TeleCo departments. The researcher was copied in on this email from Eric to Beverley, a colleague from another department, who had requested assistance with an event:

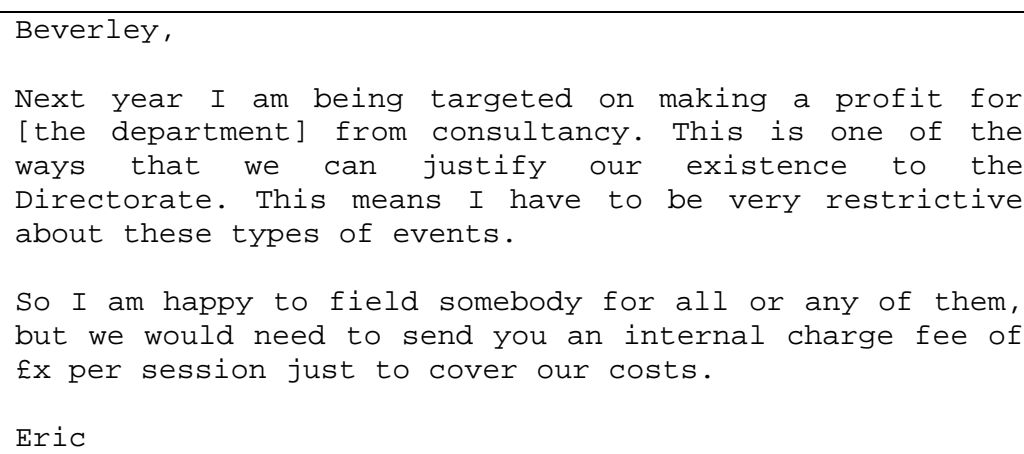

Eric was explicit here in his instrumental attitude to 'working around' the accounting system. As de Certeau (1998: 37) observed, "a tactic is an art of the weak ... Power is 
bound by its very visibility." He knew how to 'play the game' to create new internal sources of income, if this was how they were to 'justify their existence'. Ironically, this simply displaced the 'cost' of the consultants' time to another department. Yet it did mean that their 'profitability' as a business unit would appear to improve, and with it the apparent "strategic value" of their consulting activities. Given the power of numbers in defining the value of business activities, the consultants chose to tactically associate rather than dissociate (Munro, 1999) with the accounting regime.

\section{Voice and Resistance}

Whilst the MAS did achieve "individual instrumentality" (Roberts, 1991: 361) in the sense that the consultants were keen to maximise their performance-related pay and enhance their future career prospects, it did not achieve the sort of conformity and disciplinary effects found in earlier Foucauldian studies (see Roberts, 1991: 358-360). The consultants did not passively accept the disciplinary technology of the MAS. Business development manager Nigel was particularly vocal about his ideas for challenging and changing the accounting regime. He regularly complained about the 'distorted' picture that the accounting system generated about the 'value' they added to the firm. Nigel wanted the team to be measured according to the TeleCo products and services they sold as a result of the consulting work with clients, not their income from fees. One "creative" idea he had was to offer clients a discount on consulting services if they subsequently purchased a particular volume of technology. This would radically change the way they pursued consulting business. It would mean directly supporting the sale of technology, not trying to compete in an already crowded management consulting market. Another idea he had was to offer 'free' advice and support to existing sales bids. As he explained in our interview:

"The [government funded client work] is a case in point. [Those clients are] not going to spend much on technology. They may not buy any. So where is the value added? ... I think we should be out there supporting the major bids, offering our services, making things happen. When we know there's a major bid on the go, lets get inside within TeleCo, can we add value to this opportunity for you? ... [My colleagues are] going outside of the flexible working bit. They're getting into the corporate culture and 10 people can't do a culture change program. You need a massive capability. ... There are hundreds of people out there who are capable of doing cultural changes. ... If they're diversifying to that degree I see even less reason to charge the client. Let's add value to the selling relationship." 
Nigel also questioned whether the consulting packages they offer actually did facilitate technology sales - and by definition the "strategic value" of their idea. He points to clients who had bought consultancy and not bought technology, and clients who have bought considerable volumes of technology after several free presentations, without ever purchasing their consulting packages.

"There's not a single government client who hasn't had the input from us, but they've not all bought consultancy. ... They just had the benefit of 3 or 4 presentations at various stages. On the other hand we've had clients where we've done the 25-30K of consultancy and that's been the end of it. We take them to full feasibility then they stop. They've not done implementation. They've not bought any technology. Where's the value? If we did something a bit creative, [for example] if you buy half a million technology at the end it will be discounted by the amount you spent on consultancy. That adds value. You can measure that. But who am I to say.”

Nigel seemed to be careful to stress that his motive was generating value for his employers TeleCo, not simply maximising his bonus payments or avoiding redundancy. He presented himself as genuinely frustrated that the MAS was hindering his ability to generate profit and help clients.

Nigel was not alone in his views. Darren also told the researcher, during a lunch break at an event, that he thought the way they were measured, and the behaviour that encouraged, was flawed. He explained how the system paradoxically made generating consulting fee income difficult. This was somewhat self-defeating for an accounting system that was designed to encourage 'intra-preneurship’ (du Gay, 1996). FlexiTeam seemed to find it hard to convince clients to purchase consultancy from a company they were buying products and services from. Darren used the analogy of a customer refusing to pay extra for the instruction manual that comes with their television. Kevin put forward a similar argument in a team meeting. He questioned the value of their consulting offering for clients and their employing firm when he stated:

"I have difficulty believing that clients can be convinced to spend $50 \mathrm{~K}$ just deciding what it is they want."

These responses to the accounting system cannot be categorised as 'resistance' as such. The consultants did not resist the imperative to be 'intra-preneurs' (du Gay, 
1996) seeking innovative new ways to generate profit. In fact, many felt the accounting system discouraged or distracted from this, looking instead for better ideas on how to generate competitive advantage. It was in fact their apparent commitment to being 'profitable' and 'adding value' that stimulated these criticisms. They saw the accounting regime as distracting, distorting and disturbing their ability to generate 'added value'. Their response was that it encouraged precisely the wrong 'unproductive' sort of behaviour. They wanted to resist, but remain within the 'game' (Bourdieu, 1993: 74).

\section{Discussion and Conclusion}

In this paper we have drawn on a range of theorists in order to understand how management accounting systems act as a 'macro actor' (Helgesson and Kjellberg, 2005), in deciding which ideas succeed and which fail in becoming regarded as "strategic". Specifically, we have analysed the political tactics employed by a group of employees to build a case for the 'strategic value' of their idea. Our findings show how management accounting systems (MAS) are implicated in the construction of 'added value' and, in turn, the construction of 'strategic' ideas. We argue that MAS are not a neutral, technical method for controlling organizational resources, but rather a power-laden network of human and non-human actors (such as accountants, technical standards, computer systems, paperwork, regulatory bodies etc) that construct what is seen as 'value adding' activities. Whilst existing research has applied ANT to the study of accounting, our study provides several new contributions to existing debates.

Munro (1999: 429) argued that within "technologies of managing, particularly accounting numbers, ... 'centres of discretion' are created simultaneously alongside 'centres of calculation'”. Munro (1999) focuses on practices of dissociation to emphasise the discretion present in actor-networks. Our study supports Munro's argument that actors are not "intermediaries without discretion" (p. 433). We have revealed numerous practices of dissociation, such as where the participants attempted to publicise the "unfaithful" nature of the accounting regime. However, our study goes further by revealing practices of tactical association, such as where they practiced resistance by working in and through the accounting system (for example by "fiddling" the numbers). Our study paints a rich picture of the various ways in which "accounting information can be used, appealed to and even ignored" (Power, 1997: 
94). The tactical association we observed was designed as a "move" within a political "game" to enhance the power of the protagonists' "idea", acting simultaneously through and in resistance to the "centre of calculation” (Munro, 1999: 432) of the accounting regime. This supports de Certeau's argument that places emphasis on tactics, which are used by outsiders, vis-a-vis strategies, which are used by those in power. The consultants in our study, it seems, perceived a contradiction within the dominant system that they sought (albeit unsuccessfully) to exploit. As Ahrens and Chapman (2007a: 7) argue, research must be careful not to privilege the perspective of management a priori. Following this, our study deliberately follows those at the periphery of the strategy-making agenda.

A performative perspective on accounting (Callon, 1998a) requires us to understand how organizational control systems measure and reward certain types of contributions (Power, 1997: 79-90). As a result, "organisational objectives are ... influenced by the knowledge of potential accountings” (Ahrens \& Chapman, 2007a: 2), as senior management use accounting calculations to "evaluate and intervene" (ibid: 3) in organizational activity. Functionalist literature presents MAS as techniques for measuring performance, motivating behaviour and rewarding valuecreating activity (Young, Van der Stede and Gong, 2006). However, in our study the accounting system was seen by the participants as an unfaithful and unfair system for measuring the contribution made by their unit. The consultants questioned the role of the MAS as "neutral arbiter of organizational truth" (Roberts, 1991: 355). Our findings resonate with Mouritsen's (1999) study, which uncovered two competing constructions by the CEO and the production manager of what 'flexibility' meant: the former used accounting numbers to argue for outsourcing as the solution, whereas the latter saw the numbers differently and preferred investment in new technology. Thus, accounting systems act to shape the strategic agenda by crafting "particular accounts of what was profitable and what costly" (Ahrens and Mollona, 2007: 328). To our protagonists, the MAS was viewed as an unfaithful mis-representation, to others it was a faithful representation of value-adding activity. MAS are, therefore, interpretively flexible in the sense that they do not speak a single "truth" but are interpreted in different ways by different actors.

The findings of this study are relevant in particular to the study of Knowledge Intensive Firms, which are characterized by an intangible knowledge product that is both ambiguous and based largely on rhetoric/reputation (Alvesson, 1993). MAS are 
designed to help to render complex, ambiguous and opaque work activities visible, so they can be quantified, monitored and controlled: turning the invisible into the visible and the qualitative into the quantitative (Power, 1997, Strathern, 2000). In the case of KIFs specifically, with their ambiguity and intangibility, "management accounting may become embedded in situations in which there is little clarity about causation (the connection between actions taken and goals desired to be achieved)" (Baxter \& Chua, 2006: 44). Power struggles take place around the question of how to generate the "numbers" that speak the "truth" about the value of various corporate activities. While the consultants in our study were never disbanded or re-deployed during the study itself, they knew this was always potentially "on the cards" because the "numbers" were not "on their side". Not having the "right numbers" left them marginal in the strategy-making game. Our findings show the politically-laden battles over how to generate the "right numbers", as "management accounting becomes connected to processes through which various battles over scarce resources are fought and won, and individuals' reputations are preserved or tarnished” (ibid: 45). As such, we have addressed Carter, Clegg and Kornberger's (2008a) call for a better understanding of the role of power and politics in the strategy-making process. We offer a richer notion of 'practice' than existing research in the SAP field by incorporating an understanding of the micro-political tactics and power plays involved in the strategy-making process, drawing attention in particular to the role of accounting devices in this process.

Accounting numbers are powerful precisely because "the knowledge that accounting produces is presented as somehow independent of the interests of those who produce and use it” (Roberts, 1991: 359). Strategy is presented as flowing from the disinterested application of tools and technologies to a reality that exists 'out there'. In our study, accounting systems were seen by senior management as a "faithful ally" in the game of strategy formulation, making accounting calculations a key player in the battleground of organizational politics and a key "resource in the enactment of particular power relations” (Roberts, 1991: 355). According to Power (1997: 94), accounting systems "do not simply describe a pre-existing economic domain but, to varying degrees, serve to constitute a realm of facts, to make a world of action visible and hence controllable in economic terms." Our findings support Roberts' (1991: 359) argument that the "power of accounting information in organizations arises from the way it has been institutionalized as the most important, 
authoritative and telling means whereby activity is made visible”. Whilst activity is (supposedly) rendered visible, the underlying interests are made invisible. As Callon (1998b: 252-3) would say, any framing activity is always incomplete: however much effort has gone into fitting out the 'stage', for it to be at all effective, there must be a substantial unspecified network of relationships that is off-stage and invisible. In our case, however, the political tactics of a marginal, entrepreneurial group made a normally invisible MAS become (temporarily) visible and open to question.

In our case, the measuring (framing) device 'consulting-income-from-fees' that made the consultants a 'cost covering unit' had its attendant overflow: namely consultants' (increasing) anxiety, worry and unhappiness with this arrangement. We agree with others that accounting devices do not simply reflect an environment that exists independently out there. "The strategy and the environment do not exist independently of the devices, nor do the devices assume a subordinate role in implementing strategy” (Skærbæk \& Tryggestad, 2009: 3). The measuring device led to dissatisfaction and brought about intrapreneurial efforts to change the existing accounting regime.

Our study has revealed the political practices that take place on the (battle)ground before an idea enters the boardroom. Our study thereby shows how 'strategists' (or, more correctly, those seeking to be recognised as strategic players) "express their values, sentiments, and identities and pursue their various personal projects through the work they do" (Watson, 2003: 1307). These political activities are, we suggest, the very substance of strategy practice. Skærbæk \& Tryggestad (2009) suggest the notion of an 'emerging concerned group' which is not completely independent of a strategic frame but linked to it through its use, or non-use, of certain accounting devices: "If successful, the problematization conducted by emerging concerned groups can participate in reframing the strategic frame, so that these emerging concerns are taken into account." (p.4) In contrast, our 'strategists in the wild' failed to get their consulting-led selling idea onto the strategic agenda of the firm because their innovation failed to pass through the 'obligatory passage point' (Callon, 1986) of the accounting regime. Numbers proved more powerful than words in defining the strategic agenda of the firm.

We have drawn on ANT because it has been acknowledged as a promising theoretical approach for accounting research (Baxter \& Chua, 2006;_Gendron, Cooper \& Townley, 2007; Miller and O’Leary, 2007; Lounsbury, 2008). As Miller \& 
O’Leary, (2007: 710) argue, "the network is defined by the emergence and evolution of the actors and the multiple configurations they enter into". These configurations are dynamic and always-evolving as networks with a convincing discourse manage to become established and powerful, whilst other discourses become implausible and disappear (Mueller \& Carter, 2007). This dynamic process may not be apparent from the seemingly unified strategic vision "at the top", but was certainly present in our "ground level" study of the political battles of ideas. The tactics (referrals; corporate events) and language games employed by those on the periphery were not convincing enough to establish their own obligatory point of passage. A question that arises in this context is whether we have prospects to be able to distinguish tactics that are likely to be successful versus unsuccessful ones.

Finally, our study raises important questions about the operation of power in and through accounting systems. On the surface, the accounting regime in our study appeared to function as a taken-for-granted institution that dictated the strategic agenda of the firm. Yet, as our study has shown, the participants of our study also carved out spaces for resistance, voice and subversion within the accounting regime. Thus, our study adds to the growing body of literature that reveals how apparently powerful actor-networks also contain spaces for resistance, such as people who are allergic to onions but faced with standardised food in a fast-food restaurant, to quote Star's (1991) classic essay. As Ahrens and Mollona (2007: 308) argue, with specific reference to accounting systems, "actors are left with choices that are conditioned but not determined by the disciplining effects of programmes and technologies".

\section{Acknowledgements}

The authors would like to thank the UK Economic and Social Research Council (ESRC) for supporting the research upon which this article is based; grant numbers 00429934467 and 026270239.

\section{References}

Ahrens, T. and Mollona, M. (2007), "Organisational control as cultural practice - A shop floor ethnography of a Sheffield steel mill”, Accounting, Organizations and Society Vol. 32, pp. 305-331.

Ahrens, T. and Chapman, C. (2007a), "Management accounting as practice", Accounting, Organizations and Society Vol. 32, pp. 5-31. 
Ahrens, T, Chapman, C., (2007b) "Doing qualitative field research in management accounting: positioning data to contribute to theory", In: Chapman, C., Hopwood, A. and Shields, M. (eds) Handbook of Management Accounting Research, Oxford, Elsevier, pp. 299-318.

Alvesson, M. (1993),. "Organizations as rhetoric: Knowledge-intensive firms and the struggle with ambiguity”. Journal of Management Studies Vol. 30, No. 6, pp. 997-1015.

Alvesson, M. and Willmott, H. (eds) (1992), Critical Management Studies, London, Sage.

Alvesson, M. and Willmott, H. (1996), Making Sense of Management, London, Sage.

Barley, S. R. and Kunda, G. (2001), “Bringing Work Back In”, Organization Science Vol. 12, No. 1, pp. 76-95.

Baxter, J. and Chua, W. (2006), "Reframing management accounting practice: a diversity of perspectives" in A. Bhimani (Ed.). Contemporary Issues in Management Accounting, Oxford, Oxford University Press, pp.42-68.

Bourdieu, P. 1993. Sociology in Question. London: Sage

Briers, M., and Chua, W. F. (2001), "The role of actor networks and boundary objects in management accounting change: A field study of an implementation of activity-based costing”, Accounting, Organizations and Society, Vol. 26, No. 3, pp. 237-269.

Callon, M. (1986), "Some Elements in a Sociology of Translation”, in J. Law (ed.) Power, Action and Belief, pp.196-233. London: Routledge and Kegan Paul.

Callon, M. (1998a). Introduction: The embeddedness of economic markets in economics. In: The laws of the markets. M. Callon. Ed. Oxford, Blackwell: 157.

Callon, M. (1998b) An essay on framing and overflowing: economic externalities revisited by sociology, In: The laws of the markets. M. Callon. Ed. Oxford, Blackwell: 244-269

Carter, C., Clegg, S. and Kornberger, M. (2008a), "S-A-P zapping the field", Strategic Organization, Vol. 6, pp. 107-112.

Carter, C., Clegg, S. and Kornberger, M. (2008b), “Strategy as Practice?” Strategic Organization, Vol. 6, No.1, pp. 83-99

Carter, C. and Mueller, F. (2006), "The colonisation of strategy: Financialisation in a post-privatisation context”, Critical Perspectives on Accounting, Vol. 17, No. 8, pp. 967-985.

Carter, C. and Mueller, F. (2002) "The "Long March" of the Management Modernisers: Ritual, Rhetoric and Rationality”, Human Relations, Vol. 55, No. 11, pp. 1325-1354.

Chua, W.F. (1995), "Experts, networks and inscriptions in the fabrication of accounting images: a story of the representation of three public hospitals", Accounting, Organizations and Society, Vol. 20, No. 2/3, pp. 111-45.

Clegg, S., Carter, C., and Kornberger, M. (2004), “Getup, I feel like being a strategy machine”, European Management Review, Vol. 1, 21-28. 
Clegg, S., Courpasson, D. and Phillips, N. (2006), Power and Organizations. London, Sage.

De Certeau, Michel. 1984. The Practice of Everyday Life. Steven Rendall, trans. University of California Press, Berkeley.

Deetz, S. (1998), "Discursive Formations, Strategized Subordination and Selfsurveillance” in A. McKinlay and K. Starkey (eds) Foucault, Management and Organization Theory, pp. 151-72,London, Sage.

Dent, J.F. (1990), "Strategy, organization and control: some possibilities for accounting research" Accounting, Organizations and Society, Vol. 15, No. 1/2, pp. 3-25.

Dent, J.F. (1991), "Accounting and Organizational Cultures: A Field Study of the Emergence of a New Organizational Reality," Accounting, Organizations, and Society, Vol. 16, No.8, pp.705-732.

Du Gay, P. (1996), Consumption and Identity at Work. London, Sage.

Ezzamel, M. Willmott, H. and Worthington, F. (2004), "Accounting and management-labour relations: The politics of production in the 'factory with a problem'” Accounting, Organizations and Society, Vol. 29, pp. 269-302.

Ezzamel, M., Lilley, S. and Willmott, H. (1997), “Accounting for management and managing accounting: reflections on recent changes in the UK" Journal of Management Studies, Vol. 34, No. 3, pp. 439-463.

Gendron, Y., Cooper, D., and Townley, B. (2007), "The construction of auditing expertise in measuring government performance", Accounting, Organizations and Society, Vol. 32, pp. 105-133.

Helgesson, C. and Kjellberg, H. (2005), "Macro-actors and the sounds of the silenced", in B. Czarniawska and T. Hernes (eds) Actor-Network Theory and Organizing, pp. 145-164. Copenhagen, Liber.

Hoskin, K. and Macve, R. (1988), "The Genesis of Accountability: The West Point Connections", Accounting, Organizations and Society, Vol. 13, No.2, pp.3773.

Hopwood, A and Miller, P (eds) (1994), Accounting as Social and Institutional Practice, Cambridge, Cambridge University Press.

Johnson G., Melin L., and Whittington R., (2003), “Guest editors’ introduction: Micro strategy and strategizing, towards an activity-based view", Journal of Management Studies, Vol. 40, No. 1, pp. 3-22.

Knights, D., and Morgan, G. (1991), "Corporate strategy, organizations and subjectivity: A critique”, Organization Studies, Vol. 12, pp. 251-273.

Latour, B. (1987), Science in Action. Cambridge, MA, Harvard University Press.

Law J. (1986), "On the Methods of Long Distance Control: Vessels, Navigation and the Portuguese Route to India”, in J. Law (ed.) Power, Action and Belief, pp. 234-63. London, Routledge \& Kegan Paul.

Lounsbury, M. (2008), "Institutional rationality and practice variation: New directions in the institutional analysis of practice", Accounting, Organizations and Society, Vol. 33, pp. 349-361. 
Lowe, A. and Koh, B. (2007), "Inscribing the organization: Representations in dispute between accounting and production", Critical Perspectives on Accounting, Vol. 18, No. 8, pp. 952-974.

MacKenzie D. (2007), “The political economy of carbon trading”, London Review of Books Vol. 29, No. 7, 29-31.

Malone, T. (2004) 'Bringing the Market Inside’, Harvard Business Review Vol. 82, No. 4, 106-14.

Miller, P. (1994), “Accounting as social and institutional practice: An introduction”, in Hopwood, A. and Miller, P. (eds), Accounting as social and institutional practice, pp. 1-39, Cambridge, Cambridge University Press.

Miller, P. (1998), “The margins of accounting”, European Accounting Review, Vol. 7, No. 4, pp. 605-621.

Miller, P. and Napier, C., (1993), "Genealogies of calculation”, Accounting, Organizations and Society, Vol. 18, No. 7/8, pp. 631-647.

Miller, P. and O’Leary, T. (2007), “Mediating Instruments and Making Markets: Capital Budgeting, Science and the Economy", Accounting, Organizations and Society, Vol. 32, No. 7/8, pp. 701-734.

Miller, P. and O'Leary, T. (1987), “Accounting and the Construction of the Governable Person”. Accounting, Organizations and Society, Vol. 12, No. 3, pp. 235-266.

Miller, P., and Rose, N. (1990), “Governing Economic Life”, Economy and Society, Vol. 19, No. 1, pp. 1-31.

Miller, P. \& Rose, N. (2008), Governing the present: administering economic, social and personal life. Cambridge: Polity Press.

Mintzberg, H (1994), "The fall and rise of strategic planning", Harvard Business Review, Jan-Feb, pp.107-14.

Mouritsen,J., (1999) "The Flexible Firm: Strategies for a Subcontractor's Management Control”, Accounting, Organizations and Society, Vol. 24, No 1, pp.31-55.

Mouritsen, J. Hansen A. and Hansen, C. (2001), "Inter-organizational controls and organizational competencies: Episodes around target cost management/functional analysis and open book accounting”, Management Accounting Research, Vol. 12, pp. 221-244.

Mueller, F. and Carter, C. (2007), "We are all managers now': Managerialism and professional engineering in UK electricity utilities", Accounting, Organizations and Society, Vol. 32, No. 1/2, pp. 181-195.

Mueller, F. Harvey, C. and Howorth, C. (2003), “The Contestation of Archetypes: Negotiating Scripts in a UK Hospital Trust Board”, Journal of Management Studies, Vol. 41, No. 8, pp. 1971-1995.

Munro, R. (1999), "Power and Discretion: Membership Work in the Time of Technology”, Organization, Vol. 6, No. 3, pp. 429-50. 
Naranjo-Gil, D. and Hartmann, F. (2007), "Management accounting systems, top management team heterogeneity and strategic change", Accounting, Organizations and Society, Vol. 32, No.7/8, pp. 735-756.

Owen, D. (2005), “CSR after Enron: A role for the academic accounting profession?” European Accounting Review, Vol. 14, No. 2, pp. 395-404.

Potter, J. (1996), Representing Reality: Discourse, Rhetoric and Social Construction. London: Sage.

Power, M. (1997), The Audit Society: Rituals of Verification. Oxford: Oxford University Press.

Preston, A. (2006), "Enabling, Enacting and Maintaining Action at a Distance: An Historical Case Study of the Role of Accounts in the Reduction of the Navajo Herds”, Accounting Organizations and Society, Vol.31, No.6, pp.559-78.

Quattrone, P. (2004), “Accounting for God. Accounting and Accountability Practices in the Society of Jesus (Italy, 16th-17th centuries)", Accounting, Organizations and Society, Vol 29, No. 7, pp. 647-683.

Roberts, J. (1991), “The Possibilities of Accountability”, Accounting,Organizations and Society, Vol. 16, No. 4, pp. 355-68.

Robson, K. (1992), “Accounting numbers as "Inscription": Action at a distance and the development of accounting”, Accounting, Organizations and Society, Vol. 17, No. 7, pp. 685-708.

Rose, N. (1999), Governing the Soul, 2nd edn. London, Free Association Books.

Sillince, J., and F. Mueller (2007), 'Switching strategic perspective: The reframing of accounts of responsibility'. Organization Studies 28, No. 2, pp. 155-176

Skærbæk, P. \& Kjell Tryggestad. (2009), "The role of accounting devices in performing corporate strategy”. Accounting, Organizations and Society, Vol. 34(8): 887-894

Star, S.L. (1991), "Power, technologies and the phenomenology of conventions: on being allergic to onions", in Law, J. (Eds) A Sociology of Monsters? Essays on Power, Technology and Domination, Sociological Review Monograph, No. 38, pp.26-56. London, Routledge.

Strathern, M. (ed.) (2000), Audit Cultures. London and New York: Routledge

Watson, T.J. (2003), "Strategists and Strategy-Making: Strategic Exchange and the Shaping of Individual Lives and Organizational Futures”, Journal of Management Studies, Vol. 40, No. 5, pp. 1305-1324.

Whittington, R. (2004), "Strategy after modernism: recovering practice”, European Management Review, Vol. 1, pp. 62-68.

Whittington, R. (2003), “The work of strategizing and organizing: for a practice perspective”, Strategic Organisation, Vol. 1, No. 1, pp. 110-127.

Whittington, R. (1996), “Strategy as practice”, Long Range Planning, Vol. 29, No. 5, pp. 731-735.

Young, S. , Van der Stede, W. \& Gong, J (2006) “Organization control and management accounting in context: a case study of the US motion picture industry”, In: Bhimani, Alnoor, (ed.) Contemporary issues in management 
accounting. Oxford University Press, Oxford, pp. 407-424 
Appendix - Table of fieldwork data collection

\begin{tabular}{|c|c|c|c|c|}
\hline Fieldwork Event & Number & $\begin{array}{l}\text { Approx length } \\
\text { per event } \\
\text { (hours) }\end{array}$ & $\begin{array}{l}\text { Approx total } \\
\text { hours }\end{array}$ & $\begin{array}{l}\text { Method of data } \\
\text { recording }\end{array}$ \\
\hline $\begin{array}{l}\text { Meetings to } \\
\text { negotiate access }\end{array}$ & 5 & 2 & 10 & Field-notes \\
\hline $\begin{array}{l}\text { Team meetings } \\
\text { (monthly) }\end{array}$ & 5 & 7 & 35 & $\begin{array}{l}\text { Field-notes and } \\
\text { tape-recordings }\end{array}$ \\
\hline Client visits & 2 & 3 & 6 & Field-notes \\
\hline $\begin{array}{l}\text { Consultancy } \\
\text { Workshops }\end{array}$ & 1 & 6 & 6 & Field-notes \\
\hline $\begin{array}{l}\text { Performance } \\
\text { reviews }^{1}\end{array}$ & 4 & 1 & 4 & Field-notes \\
\hline $\begin{array}{l}\text { Social events } \\
\text { (lunches, drinks } \\
\text { after work etc) }\end{array}$ & Various & Various & Various & Field-notes \\
\hline $\begin{array}{l}\text { Work } \\
\text { shadowing/internal } \\
\text { meetings }\end{array}$ & 3 & 4 & 12 & Field-notes \\
\hline Home visits & 1 & 5 & 5 & Field-notes \\
\hline Interviews $^{2}$ & 9 & 2 & 18 & Tape-recordings \\
\hline $\begin{array}{l}\text { Audio-conferences } \\
\text { (weekly) }\end{array}$ & 16 & 2 & 32 & $\begin{array}{l}\text { Tape- } \\
\text { recordings }{ }^{3}\end{array}$ \\
\hline Emails & $>100$ & N/A & N/A & Email text \\
\hline
\end{tabular}

\footnotetext{
${ }^{1}$ The request for observing the performance review of one employee was refused for reasons that the review was "particularly sensitive".

${ }^{2}$ Semi-structured interviews were conducted with all but one of the ten consultants involved in the study. One respondent was asked several times for an interview and replied that he was "too busy". The researcher did not pursue the interview after three requests for fear of being seen as too 'pushy' and damaging the research relationship.

${ }^{3}$ Due to the quantity of tape-recorded audio-conference data the tapes were not transcribed in full (funds were not available at the time for a transcription service). The researcher made notes of the key themes of the conversations along with markers of the location on the tape to enable full transcription to be made if necessary.
} 